DOI: 10.14807/ijmp.v10i4.965

\title{
ENGLISH LANGUAGE ASSESSMENT IN BUSINESS CONTEXT: A CASE STUDY
}

\author{
Eliana Kobayashi \\ Federal Institute of Education, Science and Technology of São \\ Paulo, Brazil \\ E-mail: likobayashi@ifsp.edu.br
}

Submission: 01/16/2019

Accept: 02/10/2019

\section{ABSTRACT}

Although English language is considered an essential requirement to find a position in the Brazilian work market, little do we know about what proficiency level is expected from workers by companies and how language assessment occurs at work. This investigation was developed in an automation company located in São Paulo metropolitan area. It is a case study which aimed to better understand the language use expectations and analyze the assessment process to identify: the assessment tools used in the company, its language view and if the assessment process meets the company's language use expectations. This study uses questionnaires, interviews and documents analysis for data collection and triangulation of sources. The company is a place where English is used in daily tasks due to international partnerships and taught in an in-company course. The results show a mismatch between the proficiency and achievement tests applied in the company and its language view. In addition English language is a gatekeeper in recruitment process only for some positions. The language use expectations for workers vary according to their position and department but are not assessed likewise.

Keywords: English language assessment; English for Specific Purposes; business context 
DOI: 10.14807/ijmp.v10i4.965

\section{INTRODUCTION}

In the Brazilian job market, English language is considered an essential requirement to find a position. Although it seems to be common knowledge, little do we know about what proficiency level is expected from workers by companies and how language assessment occurs at work. On the other hand these questions can be considered relevant aspects especially in a globalized world where English is the main language in fields like business, technology and science (GRADDOL, 2000). While companies search for skilled professionals, applicants struggle to get a position and step up in their careers.

Thus apart from the two sides involved in such scenario: professionals and companies or employees and employers, there are also language schools and English teachers who are hired by companies to work on screening process or to teach their staff. Professionals regardless of the area also usually enroll in English courses to get prepared for job selections and meet work demands. Therefore, the language seems to be considered a gatekeeper in hiring and promoting processes.

Having said it, language assessment plays an important role in companies as eventually it is through tests that skills are measured and applicants and employees future may be influenced. Understanding how and why tests are applied and when and who takes them is essential to infer what language and proficiency views underline such assessment process.

Therefore it is possible to see that companies are important places to investigate and better understand English influence as it is fair to say that language impacts the work of many professionals. Such relation between English and employability shows the relevance of assessment research in the area.

This investigation was developed in an automation company located in São Paulo metropolitan area. It is a case study which aimed to better understand the language uses expectations and analyze the English assessment process conducted in the company to answer the following research questions: 1) Which assessment tools are used?; 2) which language and proficiency views can be inferred?; 3) Does the assessment process meets the company's language use expectations?

This context was chosen due to three main reasons. First, English was the foreign language used in the company by directors and some employees. Besides, 
there was an in-company English course to better train employees and the application of proficiency tests in hiring process. Thus, it is possible to see how language played an important role in the company in terms of learning and assessment being for these reasons a relevant context to be investigated.

\section{LITERATURE REVIEW}

Language tests can be used for several reasons and situations in society. In schools they are regularly applied to check if learning has been effective, companies test applicants before hiring and promoting, immigration applications also require passing tests, among other uses. Thus in practical terms, language assessment occurs in situations where the language is the main subject to be assessed or it is the means which allows the applicants to show their skills like in job interviews.

Therefore some tests can be considered high-stakes since their results can affect candidates' future (MADAUS, 1998). For this reason, investigating their uses is of paramount importance in many contexts like in companies.

There are different types of language tests like proficiency, achievement, placement (HUGHES, 1989) each one used for specific purpose and objective. Proficiency tests are applied to see how candidates can use the language in future situations regardless of their learning or the language program they have studied. As Vallete $(1977$, p. 6) claimed "the aim of proficiency test is to determine whether their (the students') language ability corresponds to specific requirements".

Besides proficiency tests are based on job analysis which focusses on such future use of the language in specific contexts such as academic and business ones. In the latter, the objective is to assess candidates' ability to perform tasks required for the position using the target language, for example work as a secretary in an English company. Thus there is no reference to the language courses that the applicants may or may not have taken (HUGHES, 1988).

On the other hand, achievement tests are related to the past since their purpose is to collect evidence during and at the end of a course to assess learning progress. According to Anastasi (1976, p. 398), "they are designed to measure the effects of a specific programme of instruction or training".

However, Hughes (1988) points out that successful results in achievement tests do not mean necessarily a certain proficiency acquisition since the course may be 
deficient even when it was designed to achieve such proficiency. Wiseman (1961) had already criticized the syllabus content approach because it tends to perpetuate ineffective educational practices, proposing the goal-oriented test which evaluates learning according to the curriculum.

Hughes (1988) argues the problem is the different ways in which the contents of the two tests, proficiency and achievement, are determined while they should be essentially the same. The course objectives should be according to what students are expected to perform by the end of the course reflecting the needs analysis.

Such gap between proficiency and achievement tests become even more problematic in investigation contexts like this one where the former are applied in screening processes and the latter is used in the English course for the employees.

On the other hand, proficiency tests when designed based on the expected uses of the language have proved to be effective in business contexts as discussed by McNamara (1990), Cole and Neufeld (1991) and Sajavaara (1992).

According to Douglas (2008), there are two aspects which distinguish specific purpose testing from more general purpose language testing, authenticity of task and the interaction between language knowledge and specific purpose content knowledge. Authenticity means that the tasks should be similar to the ones in the target language use. Thus it would increase the likelihood that test takers will do the test task in the same way as they would probably carry out in the actual target situation. The author also emphasizes that the interaction between language knowledge and content knowledge is the clearest defining feature of language for specific purpose testing.

Taking it into account, proficiency tests in business contexts should assess English for Specific Purposes and reflect as much as possible language use situations likely to happen in real life. As a consequence content knowledge has an important role. Due to these reasons, performance assessment can be considered the most adequate way of testing applicants' skills for a company's position.

In performance based tests, language skills are assessed in an act of communication and are most commonly tests of speaking and writing. A sample of speech in the context of simulations of real-world tasks is elicited from the test-taker and judged by raters who follow rating procedure (MCNAMARA, 2000). 
There are two traditions in second language performance assessment: the work sample and the psychological and cognitive tradition. This investigation follows the former since this approach is illustrated in language testing for specific occupational purpose. As the key for such approach is the realistic representation of relevant real world task in the test setting, McNamara (1999) emphasizes the difference between the criterion (relevant communicative behavior in the target situation; a series of performances subsequent to the test) and the test (a performance or series of performances simulating, representing or sampled from the criterion). Therefore, test performances are used as basis for making inferences about criterion performances.

Other testing foundation is its validity which has many aspects like content, criterion-related, construct and face. On the other hand, for this investigation the content validity is seen to be the most important. For Hughes (1989), a test is said to have content validity if it has a representative sample of the language skills and relevant structures with which is meant to be concerned. Therefore, in order to judge a test validity there needs to be a specification of the skills or structures that the test is meant to cover. Thus a comparison of the test content and its specification is the basis for judgments as to content validity (HUGHES, 1989).

As a conclusion, it is possible to see that building and using English language tests involve many foundation aspects which if not present can end up causing negative effects to the assessment process and affect both test users and applicants.

\section{METHODOLOGY}

This research is a qualitative case study developed in a medium-sized automation company located in São Paulo metropolitan area where English language was used in some of their daily tasks, taught to employees and was also tested in recruitment process. According to Adelman et al (1976), a case study is strong in reality and for this reason it appeals to practitioners who can identify with the raised issues. In addition, the insights from a case study can be put into use for a variety of purposes like staff development, within-institution feedback, formative evaluation and educational policy-making.

Yin (1984, p. 23) also states it is "an empirical enquiry that investigates a contemporary phenomenon within its real-life context; when the boundaries between 
phenomenon and context are not clearly evident; and in which multiple sources of evidence are used".

For this reason, the participants were selected for having a meaningful role in language use situations: the employees (students) who were taking English course; the Human Resources supervisor for being responsible for recruitments; and the director as he interviewed the candidates in English in order to assess their language level.

The data were collected using questionnaires with the students and the HR supervisor and an interview was conducted with the director. The practicability was the main factor for selecting the questionnaire as a tool since it could be sent to the participants. As stated by Nunan (1992) questionnaire enables the researcher to collect data in field settings and the data are more possible to be quantified than discursive data. In a context where employees face hard and busy routine, data collection, apart from being accurate, must also be feasible and practical. The students' questionnaire items were mostly closed while the items for the HR questionnaire were open ended.

On the other hand, a semi-structured interview was chosen as a tool to be applied with the director. This tool was chosen due to its possibilities of interaction which can allow findings which may not happen with others (DOWSETT, 1986). According to Seidman (1991 p. 3), "at the root of in-depth interviewing is an interest in understanding the experience of other people and the meaning they make of that experience".

Concerning language use, this participant has a key role in the company since he is the professional who speaks the most with foreign suppliers and interviews applicants in English to assess their level. Thus, analyzing his language view is essential to understand the company expectations related to language learning and how it assessed.

In addition, language tests used in the in company English course and the ones applied in the screening process were also analyzed.

The data collected from different sources were then triangulated. Triangulation is a technique very used in qualitative research based on the use of multiple sources 
of data aiming at increasing the reliability of the conclusions. As Bryman (1988) claimed it is an attempt to draw conclusions with more confidence.

According to Denzin (1978), there are four types of triangulation techniques: sources, methods, researchers and theories. The most used ones pointed by the authors were also applied in this investigation the sources and methods. The objective of using different sources of data and methods is to decrease the bias of one technique to compensate with another (LINCOLN, GUBA, 1985).

\section{RESULTS}

The collected data involved different sources such as the company's director, the Human Resources supervisor, the workers and the proficiency test applied in recruitment process as well as the achievement test used in the in-company English course. With the triangulation results it was possible to gather evidence to clarify this research questions.

Concerning the first and the second questions about the assessment tools used in the company and the inferences that could be made about the underlying language views, the results showed some problems in the written and oral tests applied in the recruitment process and in the achievement tests. However in order to better understand them it is necessary to discuss the language use needs in the company.

English interviews with job applicants are conducted by the director when the recruitment process is for some specific positions such as: managers, engineers and technicians who will work in technical areas of the company. Although there are other departments in the company and positions ranging from production line workers to directors, not all of them must use the language and go through testing process in case of hiring and promoting. What justifies such need is related directly to the company's business and strategies.

As they must use a specific technology provided by an American company, all workers involved directly to it are expected to know English at a level set according to their duties. For this reason, an engineer, for example, who works in an area that is not related to such supplier has different language demands from those who belong to automation area. The table below shows the positions and the main tasks expected to be performed in the language. 
INDEPENDENT JOURNAL OF MANAGEMENT \& PRODUCTION (IJM\&P)

http://www.ijmp.jor.br

v. 10, n. 4, Special Edition IFLOG 2018

ISSN: 2236-269X

DOI: 10.14807/ijmp.v10i4.965

Table 1: Positions and expected language performance in English

\begin{tabular}{|c|c|c|c|c|c|c|}
\hline Tasks & Director & $\begin{array}{c}\text { Project } \\
\text { Manager }\end{array}$ & $\begin{array}{c}\text { Engineers, } \\
\text { technicians } \\
\text { (automation } \\
\text { area) }\end{array}$ & $\begin{array}{c}\text { Engineers, } \\
\text { technicians } \\
\text { (other } \\
\text { areas) }\end{array}$ & $\begin{array}{c}\text { Purchasing } \\
\text { area }\end{array}$ & $\begin{array}{c}\text { Export } \\
\text { Import } \\
\text { area }\end{array}$ \\
\hline $\begin{array}{c}\text { Write and read } \\
\text { emails }\end{array}$ & $\mathrm{X}$ & $\mathrm{X}$ & $\mathrm{X}$ & $\mathrm{X}$ & $\mathrm{X}$ & $\mathrm{X}$ \\
\hline Read manuals & $\mathrm{X}$ & $\mathrm{X}$ & $\mathrm{X}$ & - & - & - \\
\hline $\begin{array}{c}\text { Talk on the } \\
\text { phone with } \\
\text { foreigners }\end{array}$ & $\mathrm{X}$ & $\mathrm{X}$ & $\mathrm{X}$ & - & $\mathrm{X}$ & $\mathrm{X}$ \\
\hline $\begin{array}{c}\text { Receive English } \\
\text { speaking visitors }\end{array}$ & $\mathrm{X}$ & $\mathrm{X}$ & $\mathrm{X}$ & $\mathrm{X}$ & - & - \\
\hline $\begin{array}{c}\text { Take part as a } \\
\text { listener in } \\
\text { conference calls }\end{array}$ & $\mathrm{X}$ & $\mathrm{X}$ & $\mathrm{X}$ & $\mathrm{X}$ & - & - \\
\hline $\begin{array}{c}\text { Take part and } \\
\text { give opinions in } \\
\text { conference calls }\end{array}$ & $\mathrm{X}$ & $\mathrm{X}$ & $\mathrm{X}$ & - & $\mathrm{X}$ & $\mathrm{X}$ \\
\hline Write reports & $\mathrm{X}$ & $\mathrm{X}$ & $\mathrm{X}$ & - & - & - \\
\hline Other & $\begin{array}{c}\text { Travel and } \\
\text { negotiate }\end{array}$ & $\begin{array}{c}\text { Travel } \\
\text { and } \\
\text { negotiate }\end{array}$ & - & - & - & - \\
\hline
\end{tabular}

Reading and writing are skills expected from all workers while aural skills are necessary in some areas showing that demand for the use of English in the company is not homogeneous.

There are not standardized procedures in interviews according to the director but the usual topics are applicants' working experience, reasons for leaving their previous job and expectations about the company.

The director claimed he focuses on general subjects rather than technical ones since getting to the interview phase means candidates have already passed the technical written test. Therefore it seems that the company wants candidates able to express themselves orally about general topics rather than technical ones. At this point it is possible to see that the company differs technical knowledge testing and English testing.

However talking about experience, duties and responsibilities involve technical knowledge and showing it in English interview requires specific lexis, typical expressions and register which characterize business English (PICKET, 1986). In addition, according to the director, the most important aspects considered in this oral test are: vocabulary use, interaction and pronunciation, which confirm the need for specific lexis. 
Thus such situation shows a problem between the criterion, which according to McNamara (2000) is related to relevant communicative behavior in the analyzed context, and its representation in assessment. For the company, the criterion means only general subjects and not technical ones, so the oral test does not reflect such criterion.

Non linguistics skills were also mentioned like confidence, clarity, gestures and conviction since in corporate environment workers are expected to convey a confident and reliable image. "I think you have to be confident regardless of the mistakes that can happen in a presentation or even in an interview". By "mistakes", the director mentions prepositions and time tense that he usually notices in emails exchanged between his employees and the American suppliers. However he believes that such mistakes are acceptable. On the other hand, it was clearly claimed that if communication occurs at a managerial level involving some business decisions, there should not be as many mistakes.

English can be considered a gatekeeper depending on the positions. Managers and those above technicians are not hired if they fail the language tests even passing others. However, if it happens at technician level, they can still be hired but are advised to study English since the work demands will prevent them from developing and progressing in the company.

The Human Resource supervisor is responsible for recruiting applicants and managing the English course offered to the employees, whose fee is $70 \%$ paid by the company. According to him, the course main objective is to allow workers to better communicate with the overseas suppliers, which is the same reason mentioned by the director.

The company controls the workers progress by checking the monthly report sent by the school in which attendance and marks are informed. However, the assessment report is based on a scale with "very good", "good" and "regular" but without any criteria specifications. When tests were applied, the school sent the marks that could be from zero to 10 but there was not a description of what students were supposed to be able to do after being promoted to another level. On the other side, the company regulation was to cancel the benefit in case of attendance lower than $70 \%$ and marks below six. 
It is not clearly stated what language skills are being assessed and what workers can do using the language with detailed descriptions of the criteria. There was not a course program designed according to the company's needs analysis but a regular program offered to all students who wanted to learn general English at that language school. Thus instead of having a proficiency test mark, the company received achievement tests marks which even being satisfactory would not mean necessarily the language use skills expected for the tasks workers were supposed to perform. English for Specific Purpose, in this case business English instead of general English could have been a more adequate language choice.

The data collected among workers ranked reading as the most important English skill to be used in daily tasks followed by email writing as they have to request for information and also provide information to American and German suppliers and partners. Speaking and listening skills are needed to receive visitors and take part in trainings. The collected data also showed that technical areas are those which need language the most followed by export import area. There are also departments that have little or no need to use English like finance and human resources. The latter usually resorts to the director, interviewed in this study, when recruiting applicants.

The written test applied to candidates consists of seven questions which assess language structure knowledge in isolated sentences and reading comprehension in two texts, one of them business related. Cloze was the main format of the questions but although it was believed in the 70's that integrative tests could assess several aspects of the language, more recent research has showed cloze tests assessed the same aspects as discrete items (MCNAMARA, 2000).

Therefore it can be inferred that the company's language view is more concerned with form, which can be a consequence of such tests popularity in the past and nowadays as they are still used in some language schools. However this research data points to a different view since the company main objective is to select and train workers to be able to use the language in real communication. For these reason, performance tests should be applied instead. In order to insure content validity the test would have to present authentic materials from the company like manuals and exchanged emails with overseas partners with tasks likely to be done in the company's daily routine. 
Considering the third research question "Does the assessment process meets the company's language use expectations?", the results indicated a mismatch between the company's expectations in terms of language use and the applied tests. According to the director's interview, the Human Resource supervisor and workers' data, their language view is related to business English language use skills in specific situations. On the other hand, the language view underlying the assessment tests applied in the recruitment process and by the English school focused more on structure and form of general English language knowledge indicating a more traditional approach. Such situation reflects the dichotomy use and usage (WIDDOWSON, 1978). It is important to emphasize that the problem is not related to having one view or another in a test but the mismatch between the necessary language use in a given context and the tests applied in order to attend the expectation in it.

Concerning the achievement tests, the main focus is measuring the knowledge of grammatical topics presented in the textbook, although the purpose and syllabus of the book focused on the four skills: reading, writing, listening and speaking development through communication activities. The grammar was one of the components to be studied. However, the design of the achievement test prioritized such aspect which can mean either what has been focused in class or a choice of what should be assessed. As lessons were not observed for this research, only the textbook and the tests, it can be inferred that the language view underlying the tests reflect language knowledge whereas the company's need indicates the development of language use. In addition, since achievement tests are expected to focus on the course content and objectives, such result may point to possible a traditional approach to language teaching.

In addition, as workers progress in English language is followed by monthly reports based also on achievement tests, marks may have different meanings and performance expectations in the language for company and school. For that reason, Hughes (1989) pointed out the disadvantages of achievements tests in "syllabuscontent approach" like badly designed program, badly chosen books or other material because the results could be misleading. In this research, such situation may even cause problems if workers are delegated tasks in the language which are beyond their actual proficiency. 
DOI: 10.14807/ijmp.v10i4.965

\section{CONCLUSIONS}

This paper discussed how English assessment occurred in a company where the language was used, taught by an English school and required from some workers and job applicants. The results showed mismatches concerning language views between the company and the school which affected assessment process integrated by proficiency and achievement tests. As a consequence it could influence how the company analyzed its workers' English proficiency.

There were also problems related to the tests used in recruitments process which analyzed language knowledge instead of language use. In addition, English for Specific Purposes, in this case Business English would be more adequate to the company's needs than General English. It was also found that the language can be a gatekeeper only in some positions and for certain departments. As this research was a case study it would be important if other investigations were developed in similar business contexts to better understand how English is assessed due to the increasing relevancy of this language in society.

\section{REFERENCES}

ADELMAN, C.; JENKINS, D.; KEMMIS, S. (1976) Rethinking case study: notes from the second Cambridge conference. Cambridge Journal of Education, v. 6, n. 3, p. 139-150.

ANASTASI, A. (1976) Psychological testing. New York: Macmillan.

BRYMAN, A. (1988) Quantity and Quality in Social Research. London: Unwin Hyman Publications.

COLE, G.; NEUFELD, D. (1991) Les tests d'evaluation de langue second de la function publique du Canada. Actes du Colloque Bulletin: Association quebequoise des enseignants du francais langue seconde. Ottawa: University of Ottawa.

DENZIN, N. K. (1978) Sociological methods. Nova York: McGraw-Hill.

DOUGLAS, D. (2000) Assessing Language for Specific Purpose. Cambridge: Cambridge University Press.

DOWSETT, G. (1986) Interaction in semi-structured interview. In: M. Emery:

Qualitative Research. Canberra: Australian Association of Adult Education.

GRADDOL, D. (2000) The future of English? The British Council.

HUGHES, A. (1988) Achievement and Proficiency: The Missing Link? In Hughes, A. (ed) Testing English for University Study. ELT Documents: 127. Modern English HUGHES, A. (1989) Testing for language teachers. Cambridge: Cambridge University Press. 
LINCOLN, Y. S.; GUBA, E. G. (1985) Naturalistic Inquiry. Beverly Hills: Sage. MADAUS, G. (1988) The influence of testing on the curriculum. In: TANNER, L. N. (ed). Critical issues in curriculum. Chicago: Chicago University Press, p. 83-11. MCNAMARA, T. (1990) Item Response Theory and the validation of an ESP test for health professionals. Language Testing, v. 7, p. 52-77.

MCNAMARA, T. (2000) Language Testing. Oxford: Oxford University Press.

MCNAMARA, T. (1999) Performance Testing. Encyclopedia of Language and Education, v. 7, p. 132-137.

NUNAN, D. (1992) Research Methods in Language Learning. Cambridge: Cambridge University Press.

PICKET, D. (1986) Business English: falling between two styles. Comlon, n. 26.

SAJAAVARA, K. Designing tests to match the needs of the workplace. In: SEIDMAN, I. E. (1991). Interviewing as qualitative research: A guide for researchers in education and the social sciences. New York, NY, US: Teachers College Press.

VALETTE, R. M. (1977) Modern Language Testing. New York: Harcourt Brace Jovanovich.

WIDDOWSON, H. G.(1978) Teaching Language as Communication. London: Oxford University Press.

YIN, R. K. (1984) Case study research: design and methods. California: Sage publications. 